\title{
Regional Expression of the Platelet-derived Growth Factor and Its Receptors in a Primate Graft Model of Vessel Wall Assembly
}

\author{
Larry W. Kraiss, " Elaine W. Raines, ${ }^{\star}$ Josiah N. Wilcox, "Ronald A. Seifert, ${ }^{*}$ Thomas B. Barrett, ${ }^{\star}$ Thomas R. Kirkman, * \\ Charles E. Hart," Daniel F. Bowen-Pope, ${ }^{*}$ Russell Ross, ${ }^{*}$ and Alexander W. Clowes * \\ Departments of * Surgery and ${ }^{\ddagger}$ Pathology, University of Washington, Seattle, Washington $98195 ;{ }^{8}$ Department of Medicine, \\ Emory University, Atlanta, Georgia 30322; and "Zymogenetics Corporation, Seattle, Washington 98195
}

\begin{abstract}
Healing baboon polytetrafluoroethylene grafts express PDGF mRNA in the neointima. Perfusates of graft segments also contain PDGF-like mitogenic activity. To extend these findings, we studied the expression and regional distribution of the PDGF protein isoforms and their receptors in this prosthetic graft model. By immunohistochemistry, as well as ELISA and Western blot analysis of tissue extracts, both PDGF-A and PDGF-B were identified in macrophages within the interstices of the synthetic material. In contrast, the neointima contained predominantly PDGF-A localized to the endothelial surface and the immediate subjacent smooth muscle cell layers. Tissue extracts of neointima and graft material were mitogenic for baboon aortic smooth muscle cells in culture; nearly all of this proliferative activity was blocked by a neutralizing anti-PDGF antibody. PDGF receptor $\beta$-subunit mRNA and protein were easily detectable in the neointima and graft material. PDGF receptor $\alpha$-subunit mRNA was also observed in the graft matrix and at lower levels in the neointima. This pattern of ligand and receptor expression further implicates locally produced PDGF as a regulator of neointimal smooth muscle cell growth in this model. The coexpression of ligand and receptor in the macrophage-rich matrix also suggests that PDGF may participate in the foreign body response. (J. Clin. Invest. 1993. 92:338-348.) Key words: blood vessel prosthesis • endothelium - immunohistochemistry • muscle, smooth, vascular • plateletderived growth factor
\end{abstract}

\section{Introduction}

During embryonic growth and development, endothelial cells assemble in cords, form lumina, and recruit mesenchymal cells to form the smooth muscle coat of new blood vessels (reviewed in reference 1). A somewhat similar pattern of vascular wall building is seen in healing porous ( $60 \mu \mathrm{m}$ internodal distance) expanded polytetrafluoroethylene (PTFE) ${ }^{1}$ grafts in baboons $(2,3)$. In these grafts, endothelial cells from invading trans-

\footnotetext{
Address correspondence to Alexander W. Clowes, M.D., Department of Surgery, RF-25, University of Washington, Seattle, WA 98195.

Received for publication 21 August 1992 and in revised form 10 February 1993.
}

1. Abbreviations used in this paper: PDGFR, PDGF receptors; PTFE, polytetrafluoroethylene; SMC, smooth muscle cells.

J, Clin. Invest.

(c) The American Society for Clinical Investigation, Inc. $0021-9738 / 93 / 07 / 338 / 11 \quad \$ 2.00$

Volume 92, July 1993, 338-348 mural microvessels ( or the cut edges of adjacent arteries) cover the luminal surface and form a confluent monolayer. Smooth muscle cells (SMC) subsequently appear beneath the endothelium, proliferate, and deposit extracellular matrix to form a thickened neointima (2). The neointima reaches a stable, mature state by $3 \mathrm{mo}$ and the SMC proliferation decreases to a low rate $(<1 \%)$.

This model is an example of vessel wall assembly on a noncontractile synthetic substrate. As in native vessels, graft wall structure can be regulated by hemodynamic forces such as shear stress $(4,5)$. Our laboratory has investigated factors that might regulate the growth of the neointimal lining of these prosthetic grafts. Since there is no evidence of platelet adherence two weeks after graft implantation, we have hypothesized that the signal for neointimal growth is endogenous to the graft (6). In support of that hypothesis, Golden et al. have demonstrated that the neointima expresses mRNA for PDGF-A and, upon perfusion of excised grafts, releases into the lumen a mitogenic substance whose activity is blocked by anti-PDGF antibodies ( 7 ).

The PDGF system is complex, consisting of multiple forms of dimeric ligand and receptor molecules (reviewed in reference 8). PDGF isoforms are covalently associated dimers of two distinct polypeptide subunits: PDGF-A and PDGF-B. These subunits are quite homologous but are encoded by separate genes. The three dimeric forms of PDGF ( $\mathrm{AA}, \mathrm{AB}$, and $B B$ ) represent the possible combinations of the two subunit chains A and B. Each of these dimers has been found in nature $(8,9)$. PDGF was originally described in platelets $(10)$, but has also been demonstrated in cells of the vascular wall $(8,11-13)$.

PDGF exerts its biologic effects through high affinity interactions with cell-surface receptors (PDGFR), of which there are also two types: PDGFR- $\alpha$ and PDGFR- $\beta(14,15)$. These receptor subunits possess different binding characteristics (16, $17)$. The $\alpha$-receptor can bind either the PDGF-A or B chain but the $\beta$-receptor only binds the PDGF-B subunit. For a cell to respond to PDGF-A, it must express $\alpha$-receptors on its surface but a cell expressing either $\alpha$ - or $\beta$-receptors can respond to PDGF-B chain. The biologic activity of PDGF is dependent not only on the nature of the ligand but also on the availability of relevant receptors in the target cell population. Thus, if one postulates a role for PDGF in a biologic process, the presence of the ligand and an appropriate form of the PDGF receptor should be demonstrable.

In this paper, we confirm the presence of biologically active PDGF along with receptor proteins in both the neointima and graft matrix. The colocalization of PDGF protein and receptor in the neointima suggests the possibility of a local autocrine or paracrine mechanism of SMC growth control. The presence of PDGF ligand and receptor in the graft matrix also implies a role for PDGF in the host foreign-body response. 


\section{Methods}

Graft implantation and removal. Porous (60- $\mu \mathrm{m}$ internodal distance) PTFE grafts were implanted bilaterally in the aorto-iliac circulation of anesthetized juvenile male baboons $(\sim 10 \mathrm{~kg})$ using standard vascular surgical technique $(2,7)$. Grafts were anastomosed to the arteries in end-side fashion with continuous 6-0 polypropylene suture (Davis and Geck, Danbury, CT) and native vessels were ligated so that common iliac flow on each side was diverted through the ipsilateral graft.

After $8 \mathrm{wk}$, the animals were deeply anesthetized, anticoagulated with heparin (3,000 $\mathrm{U}$ intravenously) and the aorto-iliac grafts removed, rinsed, and processed as described below. Another pair of grafts was implanted into the aorto-iliac position. $8 \mathrm{wk}$ later, the animals were again anesthetized, anticoagulated, and then exsanguinated by systemic perfusion with lactated Ringer's solution at $100 \mathrm{mmHg}$ via an axillary artery cannula with femoral venous drainage. The grafts were then rapidly removed, copiously rinsed in lactated Ringer's, and processed as described below. The data derived from tissue (a total of 12 grafts) and animals (three in number) in this study are distinct from previously published data using this model (2-7).

RNA extraction and Northern analysis. Extraction of RNA from graft tissue and Northern blotting was performed as described by Golden et al. (7). After removal, the graft material and a portion of the native aorta were quickly frozen in liquid nitrogen. The frozen tissue was homogenized in an extraction buffer containing $5 \mathrm{M}$ guanidine isothiocyanate, $10 \mathrm{mM}$ EDTA, $50 \mathrm{mM}$ Tris- $\mathrm{HCl}(\mathrm{pH} \mathrm{7.5)}$, and $8 \%$ (vol/vol) $\beta$ mercaptoethanol. Neointima, graft material, and aorta were dissected and processed separately. Total RNA was selectively precipitated with lithium chloride (18). RNA samples were then electrophoresed in $1 \%$ agarose ( $10 \mu \mathrm{g} \mathrm{RNA} /$ lane) and transferred to nylon membranes for analysis. Probes for PDGF-A (19), PDGF-B (20), PDGFR- $\alpha$ (17), and PDGFR- $\beta$ (21) were labeled with ${ }^{32} \mathrm{P}$ by nick translation, added to the hybridization solution, and incubated at $42^{\circ} \mathrm{C}$ for 20-24 h. The blots were then washed and signals detected by autoradiography. Messenger RNA from normal human aorta and adult SK-5 human skin fibroblasts were compared with graft samples.

In situ hybridization. After removal of the graft, a portion was embedded in OCT medium (Miles Laboratories Inc., Elkhart, IN) for subsequent cryosectioning and histologic analysis. Using previously described techniques $(22,23)$, cryosections were pretreated with paraformaldehyde, proteinase $\mathrm{K}$, and prehybridized in $100 \mu$ l hybridization buffer ( $50 \%$ formamide, $0.3 \mathrm{M} \mathrm{NaCl}, 20 \mathrm{mM}$ Tris, $\mathrm{pH} 8.0,5 \mathrm{mM}$ EDTA, $0.02 \%$ polyvinylpyrrolidine, $0.02 \%$ Ficoll, $0.02 \%$ BSA, $10 \%$ dextran sulfate, and $10 \mathrm{mM}$ dithiothreitol $)$ at $42^{\circ} \mathrm{C}$. Probes specific for PDGF-A (19), PDGF-B (24), PDGFR- $\alpha$, (25), and PDGFR- $\beta$ (26) were labeled by transcription (27) with ${ }^{35} \mathrm{~S}$-UTP to a specific activity of $300 \mathrm{Ci} / \mathrm{mmol}$. Serial sections were then hybridized overnight with $600,000 \mathrm{cpm}$ of labeled probe. The sections were then washed with $2 \times$ $\mathrm{SSC}(1 \times \mathrm{SSC}=150 \mathrm{mM} \mathrm{NaCl}, 15 \mathrm{mM} \mathrm{Na}$ citrate, $\mathrm{pH} 7.0)$ with $10 \mathrm{mM}$ $\beta$-mercaptoethanol and $1 \mathrm{mM}$ EDTA, treated with RNase (Sigma Chemical Co., St. Louis, MO), and followed with a high stringency wash in $0.1 \times$ SSC with $10 \mathrm{~mm} \beta$-mercaptoethanol and $1 \mathrm{mM}$ EDTA, at $55^{\circ} \mathrm{C}$ for $2 \mathrm{~h}$. Slides were then washed in SSC without $\beta$-mercaptoethanol, dehydrated in graded alcohols, coated with NTB2 photographic emulsion (Eastman Kodak Co.), placed in light-tight containers, and exposed for $4-12 \mathrm{wk}$ at $4^{\circ} \mathrm{C}$. Sections were then developed and counterstained with hematoxylin and eosin.

Immunohistochemistry. An antibody against PDGF-A was prepared by double affinity-purification of rabbit polyclonal anti-PDGF (9) and designated 4822. Limited cross-reactivity with PDGF-B chain was removed by passage over a column containing PDGF-BB coupled to Sepharose followed by purification of the anti-PDGF-A by adsorption and elution from a column containing PDGF-AA coupled to Sepharose. Monoclonal antibodies were used to detect PDGF-B chain (PGF-007) $(28,29)$ and PDGFR- $\beta$ (PR7212) (30), and to identify SMC (anti-actin HHF 35) (31) and macrophages (HAM 56) (32).

Portions of the graft specimens were rinsed with lactated Ringer's solution and immediately immersed in methyl Carnoy's fixative (60\% methanol, $30 \%$ chloroform, $10 \%$ acetic acid vol/vol) after removal from the animal. Some of the tissue was also embedded in OCT compound and snap-frozen in liquid nitrogen. 1 or $2 \mathrm{~d}$ later, the fixed specimens were switched to $70 \%$ ethanol and then processed for paraffin embedding. Fixed and frozen sections were mounted on poly-D-lysine-coated slides and immunohistochemical procedures used biotinylated second antibodies (Vector Laboratories, Inc., Burlingame, CA), avidin-biotinylated peroxidase, and diaminobenzidine: $\mathrm{NiCl}_{2}$ as the chromogen. Sections were incubated with the primary antibody overnight at $4^{\circ} \mathrm{C}$. For monoclonal antibodies, an irrelevant monoclonal antibody served as a negative control; for the polyclonal antibodies, rabbit nonimmune serum or IgG (if the primary antibody was affinity purified) was used as a negative control. All the antibodies except PR7212 gave satisfactory staining on paraffin-embedded tissue. PR7212 staining was performed on cryosections.

Competitive blocking experiments were performed with PGF-007 (anti-PDGF-B) and anti-PDGF-A (4822). For PGF-007, a 20-fold molar excess of the immunogenic peptide or human platelet PDGF was preincubated with the antibody before application to the slide (29); 5 to 10-fold molar excess of recombinant PDGF-AA was used to block anti-PDGF-A (4822) staining.

Double-labeling studies used a combination of immunoperoxidase and alkaline phosphatase techniques. Antibodies for PDGF were applied first and processed according to the avidin-biotin-peroxidase method described above. Antibodies specific for macrophages (HAM 56 ) or SMC (HHF 35) were applied second, incubated overnight at $4^{\circ} \mathrm{C}$, and developed by the alkaline phosphatase method (Vector Laboratories, Inc.).

Tissue extraction for evaluation of PDGF protein. Grafts were quickly frozen in liquid nitrogen after removal. The neointima, graft material, and perigraft tissue were separated and pooled into like fractions for extraction and analysis. In total, $25-30 \mathrm{~cm}$ of graft tissue was available for extraction. For extraction, the grafts were thawed in PBS ( $\mathrm{pH}$ 7.4) containing protease inhibitors ( $1 \mathrm{mM}$ EDTA, $1 \mathrm{mM} o$-phenanthroline, $1 \mu \mathrm{g} / \mathrm{ml}$ pepstatin, $1 \mu \mathrm{M}$ leupeptin, and 50 kallikrein inhibitory units $/ \mathrm{ml}$ aprotinin). The grafts were homogenized and extracted in $1 \mathrm{~N}$ acetic acid, $1 \mathrm{M} \mathrm{NaCl}$, and protease inhibitors for $2 \mathrm{~h}$ at $4^{\circ} \mathrm{C}$. The samples were centrifuged to remove graft particles and cellular debris and further concentrated (Centriprep 10; Amicon Corp., Danvers, MA) to a final volume of $3 \mathrm{ml} /$ fraction.

$E L I S A$. The extracts were analyzed for the presence of different forms of PDGF using dimer-specific enzyme-linked immunoassays. Using 96-well microtiter plates, the bottom of each well was incubated overnight at $4^{\circ} \mathrm{C}$ with monoclonal antibodies directed against the Achain $(127.2 .2 .2,2.5 \mu \mathrm{g} / \mathrm{ml}$ ) (9) or the B-chain (PGF-007, $10 \mu \mathrm{g} / \mathrm{ml}$ ) $(28,29)$. The remainder of the protein binding sites in the wells were blocked with BSA $(10 \mathrm{mg} / \mathrm{ml})$ for $1 \mathrm{~h}$ at $37^{\circ} \mathrm{C}$. Serial dilutions (up to $1: 32$ ) of the tissue extracts were then added to duplicate wells and incubated at $37^{\circ} \mathrm{C}$ for $90 \mathrm{~min}$. The plates were washed and rabbit polyclonal anti-PDGF-A or anti-PDGF-B (9) added to each well and incubated for $1 \mathrm{~h}$ at $37^{\circ} \mathrm{C}$, followed by a biotinylated goat anti-rabbit antibody (Vector Laboratories, Inc.) under the same conditions. An avidin-biotinylated peroxidase system (Vector Laboratories, Inc.) was used to identify bound antibody complexes and developed with $o$ phenylene diamine. After $\sim 15 \mathrm{~min}$, the chromogenic reaction was stopped by addition of $4 \mathrm{~N} \mathrm{H}_{2} \mathrm{SO}_{4}(50 \mu \mathrm{l} /$ well $)$. The spectrophotometric absorbance at $492 \mathrm{~nm}$ was determined for each well and compared to values obtained when known amounts of PDGF $A A, A B$, or $B B$ were added to each well in place of tissue extract. Extracts of baboon platelets were evaluated by ELISA as well to determine the predominant dimeric form present in platelets.

Western blotting of PDGF ligands. According to a previously described technique (33) nonreduced concentrated aliquots of tissue extract were separated on 15\% SDS-PAGE gels and transferred to nitrocellulose. After blocking excess binding sites with $1 \% \mathrm{BSA}$, the blots were incubated at room temperature for $90 \mathrm{~min}$ with primary antibodies directed against PDGF-A (a rabbit polyclonal pre-affinity-purified form of 4822) (9) or against all three PDGF dimeric forms (goat affin- 

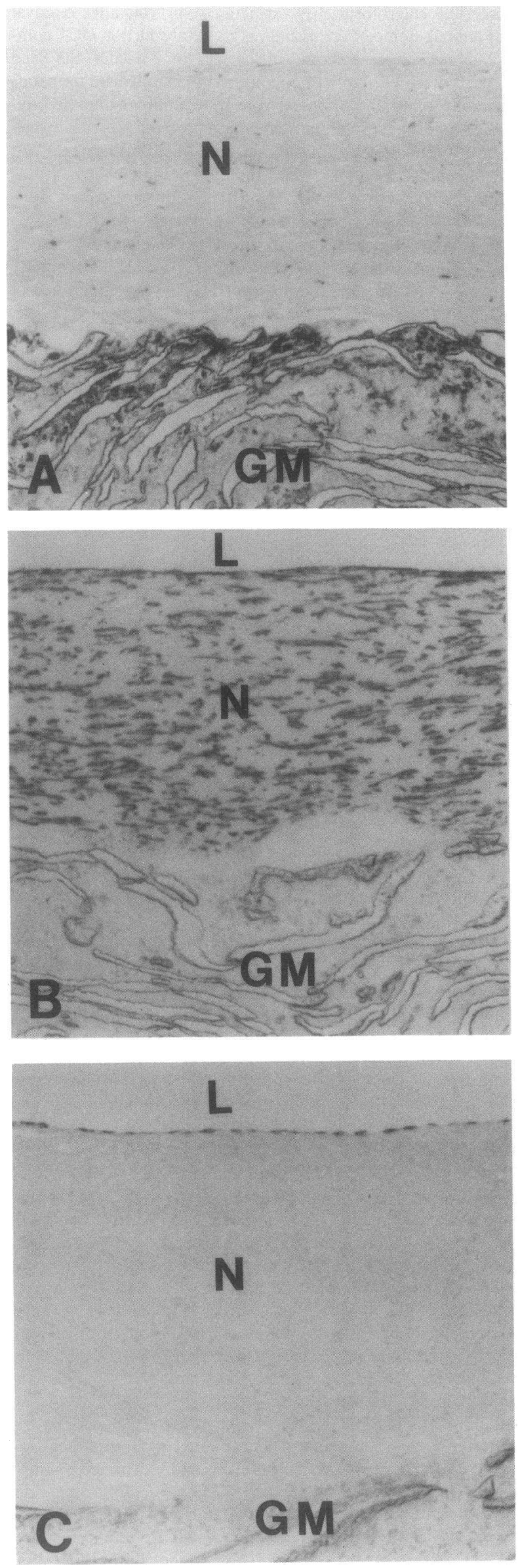

ity-purified polyclonal) (34). Species-specific biotinylated secondary antibodies and the avidin-biotinylated immunoperoxidase system were used to detect bound primary antibody. The chromogen was diaminobenzidine (Sigma Chemical Co.) in $0.05 \mathrm{M}$ Tris- $\mathrm{HCl}$ ( $\mathrm{pH} 7.25$ ) with $0.03 \%$ hydrogen peroxide. Specificity of detection by the anti-PDGF-A chain and polyclonal anti-PDGF antibodies was demonstrated by preincubation and competitive inhibition with either PDGF-AA or PDGF-AB, respectively. Baboon platelet extracts were similarly evaluated.

Mitogenesis assay. The mitogenesis assay was performed as described by Raines and Ross (35). Baboon aortic SMC in the sixth passage were plated in 24-well trays (100,000 cells/well) in $10 \%$ fetal bovine serum. The next day, the medium was switched to $1 \%$ baboon plasma-derived serum in Dulbecco-Vogt medium $(1 \mathrm{ml} /$ well $)$ and the cells were growth arrested for $72 \mathrm{~h}$. Samples of extract from the neointima and graft material were preincubated for $1 \mathrm{~h}$ at $37^{\circ} \mathrm{C}$ with neutralizing goat polyclonal anti-PDGF antibody or nonimmune goat IgG at a final concentration of $500 \mu \mathrm{g} / \mathrm{ml}$ (34). The test solutions were then added to triplicate wells and allowed to incubate for $20 \mathrm{~h}$ at $37^{\circ} \mathrm{C}$. The medium was then aspirated and replaced with $0.5 \mathrm{ml} /$ well of $5 \%$ calf serum containing $2 \mu \mathrm{Ci} / \mathrm{ml}$ tritiated thymidine (New England $\mathrm{Nu}-$ clear, Boston, MA) and incubated for another $8 \mathrm{~h}$. The radioactive medium was aspirated and the wells washed with three changes of cold $5 \%$ trichloroacetic acid. The acid-insoluble material was then dissolved in $0.25 \mathrm{~N} \mathrm{NaOH}(800 \mu \mathrm{l} /$ well $)$ and $600 \mu \mathrm{l}$ aliquots added to $5 \mathrm{ml}$ of liquid scintillation medium (Biofluor; New England Nuclear). Samples were analyzed in a liquid scintillation counter.

Tissue extraction for evaluation of PDGF receptors. After removal, grafts were rapidly frozen in liquid nitrogen. Graft matrix and neointima were processed separately. The tissue was pulverized under liquid nitrogen in a dry ice-cooled mortar and pestle and then homogenized in extraction buffer (2\% SDS, $0.1 \mathrm{M}$ Tris pH 6.8, 20\% glycerol) at a ratio of $4 \mathrm{ml}$ solution per gram of tissue.

Western blotting of PDGF receptors. After the method of Hart et al. (30), tissue extracted as described above was separated electrophoretically on $8 \%$ SDS-PAGE gels under nonreducing conditions. After transfer to nitrocellulose paper, the blots were probed with antibodies to the PDGFR- $\alpha$ subunit or PDGFR- $\beta$ subunit (PR7212). A speciesspecific alkaline phosphatase-conjugated secondary antibody was used to detect bound primary antibody. The chromogen was bromochloroindoyl phosphate/nitro blue tetrazolium. Extracts of baboon SMC known to express PDGFR- $\beta$ were used as a positive control while SMC extracted after exposure to PDGF-BB (to downregulate the $\beta$-subunit) served as a negative control. A baby hamster kidney cell-line transfected with the PDGFR- $\alpha$ subunit was used as a control for the antiPDGFR- $\alpha$ antibody in analogous fashion.

\section{Results}

Graft morphology. A total of 12 grafts all implanted for 2 mo were available for analysis. Histologic cross-sections stained with hematoxylin and eosin confirmed previous observations that an endothelialized, thickened neointima forms by 2 mo in the baboon grafts (2). Immunocytochemical studies showed that cells within the graft matrix stain heavily with HAM 56, a macrophage marker (Fig. $1 A$ ), while the neointima stains primarily with HHF 35, an anti-actin marker for SMC (Fig. $1 B$ ). Luminal cells stain with antibodies to Factor VIII-related anti-

Figure 1. Identification of constituent cells in PTFE graft model by immunohistochemistry. Cell-specific staining is black in graft crosssections incubated with $(A)$ HAM 56, a macrophage marker; $(B)$ HHF 35, a smooth muscle cell marker; $(C)$ Factor VIII antibody, an endothelial cell marker. $L$, lumen; $N$, neointima; $G M$, graft matrix. $\times 100$. 


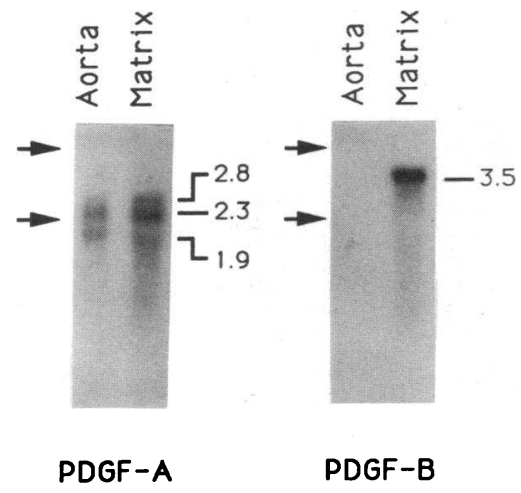

gen demonstrating the presence of endothelium (Fig. $1 C$ ). A few macrophages were also scattered throughout the neointima (Fig. $1 A$ ).

Localized expression of PDGF-A and $-B$ chain in baboon grafts. Previously reported studies using Northern blotting and in situ hybridization analyzed only the graft neointima and found mostly PDGF-A mRNA and little PDGF-B mRNA (7, 36). At the time of our previous analysis of PDGF contribution to the neointimal formation in the baboon vascular grafts (7), antibodies for immunocytochemical localization of PDGF were not available. In the present study both neointima and graft matrix were analyzed. By Northern analysis, RNA extracts of graft matrix demonstrated increased levels of transcripts for both PDGF-A and -B as compared with a normal vessel (Fig. 2). Northern analysis of the neointima revealed the presence of PDGF-A but little PDGF-B (not shown), consistent with previously reported data $(7,36)$.

Immunohistochemical studies using a monoclonal antibody to PDGF-B (PGF-007) revealed relatively intense staining (extinction or loss of signal at $16 \mathrm{ng} / \mathrm{ml}$ antibody concentration) of cells residing in the graft matrix (Fig. $3 \mathrm{~A}$ ) as well as less intense staining (extinction at $250 \mathrm{ng} / \mathrm{ml}$ ) in the neointima (Fig. $3 \mathrm{~B}$ ). Double-labeling studies identified the PDGF$B$ positive cells in the graft matrix cells as macrophages (Fig. 3 $C$ ) while the positively stained cells in the neointima consisted of both macrophages and SMC (Fig. 3, D and $E$ ). Surface endothelial cells did not appear to stain with the antibody and staining with an irrelevant monoclonal antibody at similar protein concentrations was negligible (not shown). The PGF-007 staining in the graft matrix and neointima was completely abolished by preincubation with the immunogenic peptide used to develop the antibody and with PDGF (30) (not shown).

The distribution of PDGF-A protein subunit in the graft matrix (using the double affinity-purified polyclonal anti-A antibody, 4822) (9) was similar to PDGF-B: prominent staining was observed in the cytoplasm of macrophages (Fig. $4 A$ ). Staining of the neointima was localized to a narrow periluminal region consisting of the endothelium and first few layers of SMC (Fig. $4 B$ ), a pattern very similar to that observed by Golden et al. when they performed in situ hybridization studies for PDGF-A mRNA on PTFE graft neointima (7). A nonimmune rabbit IgG antibody at equivalent protein concentration did not stain either the graft matrix (Fig. $4 \mathrm{C}$ ) or neointima (Fig. $4 D$ ). However, we were unsuccessful in competitively blocking 4822 staining with recombinant PDGF-AA; preincubation of 4822 and the control nonimmune IgG antibody with PDGF-AA yielded either artifactual nuclear staining or dif- fusely increased the level of background staining for both immune and nonimmune antibodies (not shown).

Characterization of the PDGF present in the baboon grafts. To determine which dimeric forms of PDGF are present in the baboon grafts, the tissue extracts were assayed using dimer-specific ELISAs (Table I). In the neointima, PDGF-A chain was readily detectable in the form of the AA homodimer. However, PDGF-B chain was found only in small amounts as indicated by the absence of PDGF-AB and a barely perceptible PDGF$\mathrm{BB}$ signal. These findings agree with and extend our immunohistochemical observations (Figs. 3 and 4) and are consistent with previous observations of PDGF-A and -B chain transcript in the graft neointima $(7,36)$. The extract from the graft matrix contained all three dimeric forms of PDGF, consistent with our immunohistochemical findings (Figs. 3 and 4 ) that macrophages in this region stain with antibodies to both PDGF-A and -B chain and that transcripts for both A- and B-chain can be demonstrated by Northern blotting (Fig. 2). A similar analysis of an extract of baboon platelets demonstrated that only PDGF-BB was present (Table I). This finding indicates that our observations of PDGF-AA in the neointima and PDGF-AB in the graft matrix are not the result of contamination of the graft specimens by platelet releasate. Theoretically, the presence of PDGF-BB in the graft matrix could be the result of platelet contamination, but the presence of the $A B$ heterodimer in the ELISA, the positive immunostaining with PGF-007, and the presence of PDGF-B mRNA (Fig. 2) establishes the ability of the macrophages to elaborate PDGF-B, and thus the potential to make the BB homodimer.

To characterize further the molecular nature of the extracted PDGF, Western blotting studies of the extracts were performed (Fig. 5). The rabbit polyclonal anti-PDGF-A antibody recognized two specific bands of $\sim 30$ and $65 \mathrm{kD}$, respectively, in the neointimal extract. The matrix contained two lower molecular weight bands ( 33 and $38 \mathrm{kD}$ ) as well as the higher molecular weight form seen in the neointima. The molecular weights for the PDGF-A precursor protein are 36 and $44 \mathrm{kD}$ with the mature form being $30-31 \mathrm{kD}(8)$. We ascribe the discrepancy in size between the low molecular weight forms in the neointima and matrix and the high molecular weight form in the neointima to possible differences in posttranslational processing. Detection of both the high and low molecular species was significantly decreased when the A-chain antibody was competitively inhibited with PDGF-AA, as was the detection of recombinant PDGF-AA (data not shown).

Western blots of the matrix extract were also probed with a goat polyclonal antibody that recognizes all forms of PDGF (Fig. 5). A broad band of 29-35 kD was observed as were 56and $66-\mathrm{kD}$ forms. This pattern is consistent with the size of mature PDGF (29-31 kD) and precursor forms of PDGF-BB (56 kD) and PDGF-AA (36 and $44 \mathrm{kD}$ ). These bands were largely inhibited when the antibody was preincubated with PDGF-AB. The Western blots of the neointimal extract were not probed with this antibody because of limited material and the ELISA results indicating that most or all of the PDGF in the neointima was the AA homodimer.

Tissue extracts contain mitogenic activity inhibited by anti$P D G F$ antibodies. To verify further the immunohistochemical and ELISA results and compare the tissue extracts with previous ex vivo perfusion of the grafts (7), the pooled extracts of graft neointima, matrix, or perigraft tissue were tested for the presence of mitogenic activity and the relative contribution of 

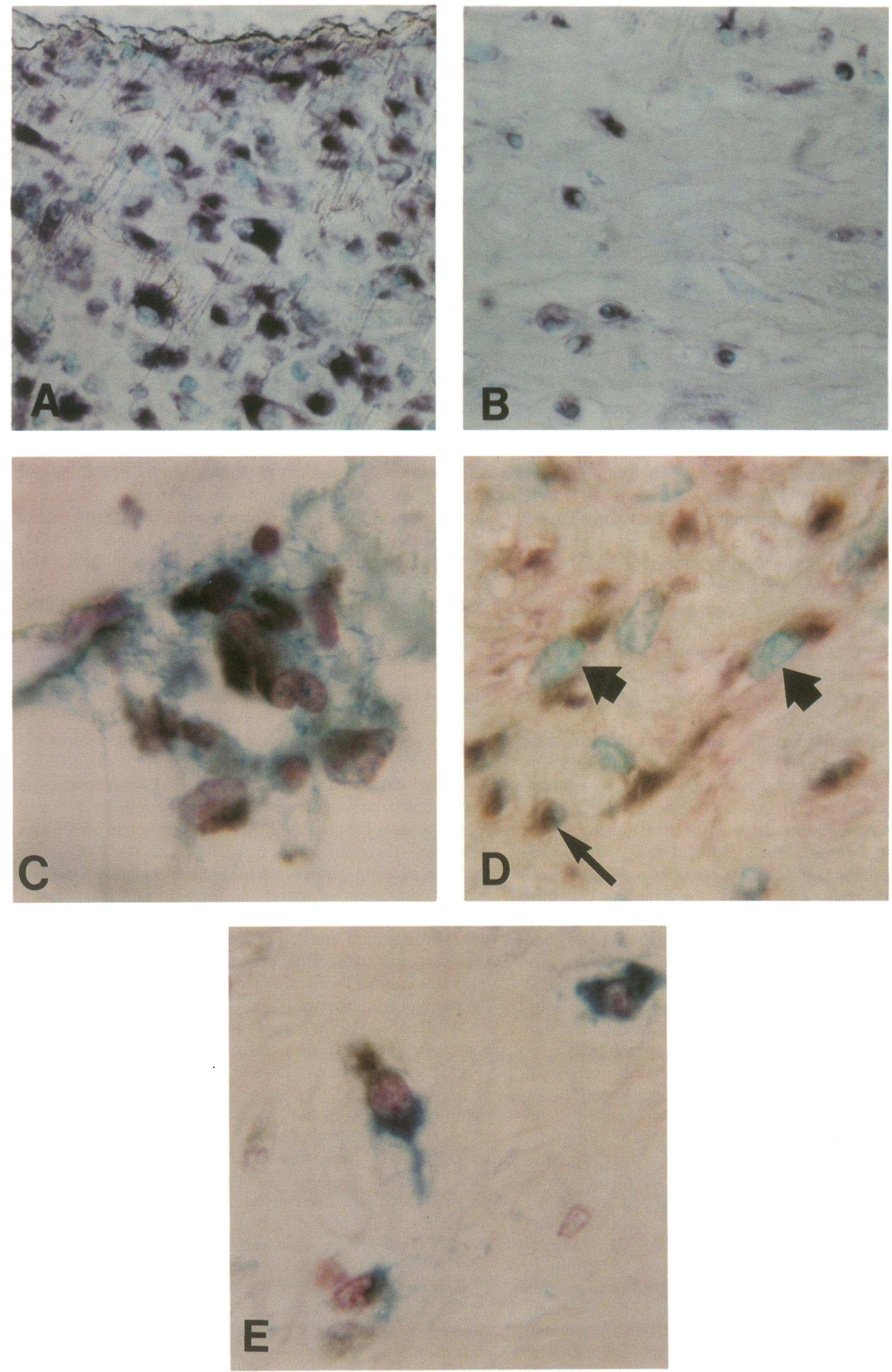

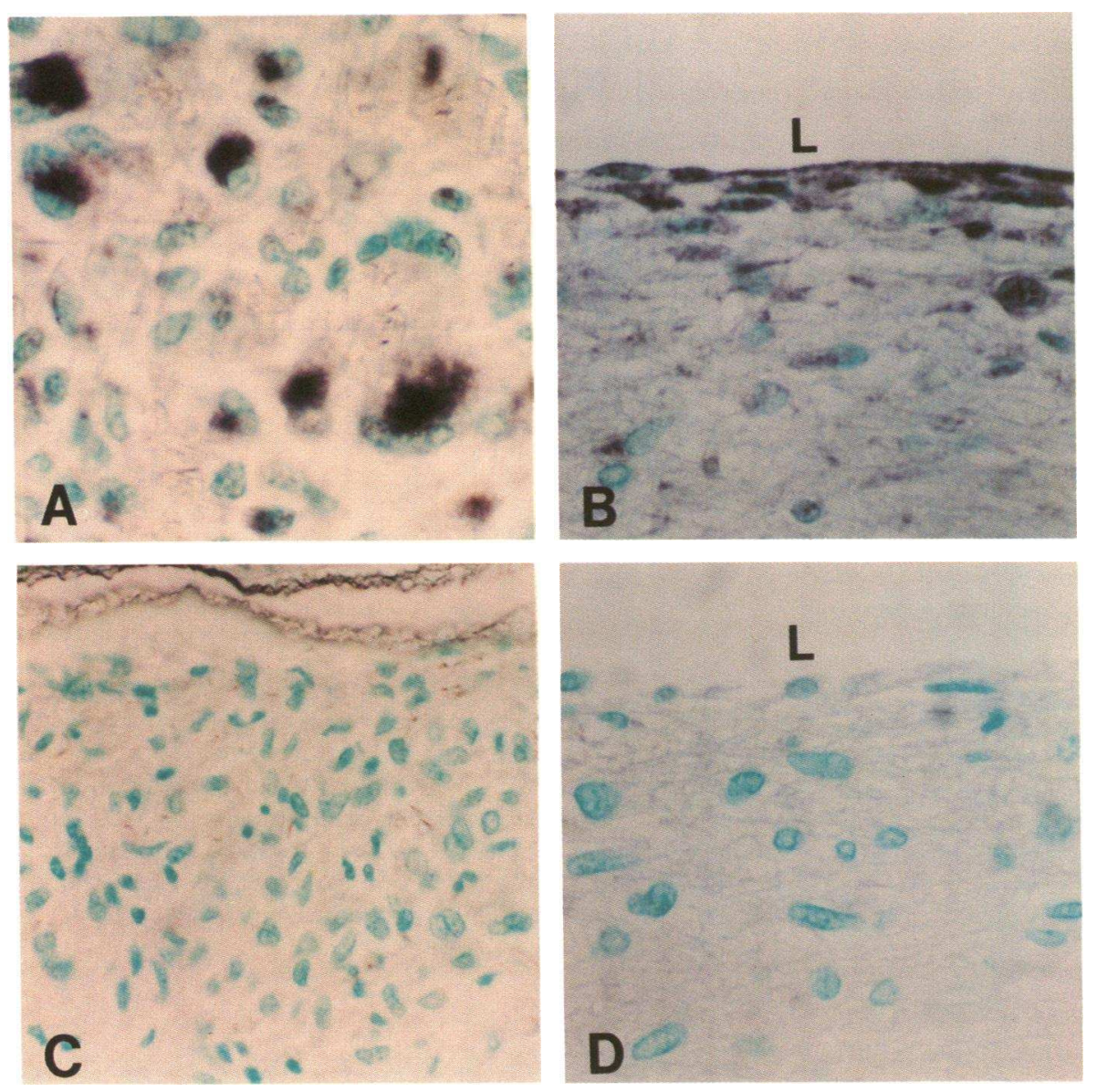

Figure 4. PDGF-A protein localization in PTFE grafts by immunohistochemistry. PDGF-A staining is black and nuclei green in $(A)$ graft matrix and $(B)$ neointima stained with $4822 ;(C)$ graft matrix and $(D)$ neointima stained with nonimmune IgG. $\times 1,000(A, B, D) ; \times 400(C)$.
PDGF (Fig. 6). The biological activity of the PDGF within the extracts was determined on baboon aortic SMC known to be responsive to all three PDGF dimers. As depicted in Fig. 6, extracts from both graft matrix and neointima stimulated DNA synthesis in these cells. Preincubation of the extract with a polyclonal anti-PDGF antibody that neutralizes all dimeric forms of PDGF significantly reduced the proliferative response to levels approaching the basal level of thymidine incorporation in the absence of exogenous mitogen. This result suggests that the major mitogen in the neointimal and matrix extract is PDGF.

PDGF receptor expression in baboon grafts. For PDGF to regulate healing and neointimal development, a relevant form of the PDGF receptor needs to be present on cells in the matrix and neointima. We investigated the expression of the PDGF receptor genes in this model using Northern analysis (Fig. 7) and in situ hybridization (not shown). In the neointima, the PDGFR- $\beta$ subunit gene is preferentially expressed over the PDGFR- $\alpha$ subunit gene (Fig. $7 A$ ). RNA extracted from the graft matrix contained transcripts for both the PDGFR- $\beta$ and PDGFR- $\alpha$ genes (Fig. $7 \mathrm{~B}$ ). The overwhelming majority of the matrix cells stain with HAM 56. These findings suggest that foreign body-activated macrophages are capable of expressing both PDGF receptor genes or that macrophages may increase receptor expression in localized mesenchymal cells.

Cryosections of the neointima in the PTFE grafts were stained with a monoclonal antibody to the PDGFR- $\beta$ subunit (Fig. 8). Diffuse staining of the neointimal cells was observed (Fig. $8 \mathrm{~A}$ ) whereas the adjacent aorta did not stain (Fig. $8 \mathrm{~B}$ ). Staining with an irrelevant monoclonal antibody was negligible (not shown). The graft matrix could not be evaluated as its morphologic appearance on frozen section is not satisfactory for immunohistochemical evaluation. None of the available antibodies to the PDGFR- $\alpha$ subunit gave specific staining on histologic sections of the PTFE graft matrix or neointima.

The presence of PDGFR $-\beta$ subunit protein was confirmed by Western blot analysis of tissue extracts from the neointima and graft matrix using the monoclonal antibody PR7212 (Fig. 9). Strongly staining bands at $180,000 \mathrm{~mol}$ wt were observed in both graft matrix and neointima extracts. Native baboon aorta contained little recognizable PDGFR- $\beta$. These data are in agreement with the immunohistochemical findings presented

Figure 3. PDGF-B protein localization in PTFE grafts using the monoclonal antibody PGF-007. The following regions of the graft were stained with PGF-007: $(A)$ PTFE graft matrix, and $(B)$ neointima, in which cells staining with PGF-007 appear black and nuclei are stained green; $(C)$ graft matrix double stained with PGF-007 (brown) and the macrophage marker, HAM 56 (blue) with nuclei counterstained red; (D) neointima double stained with PGF-007 (brown) and the smooth muscle marker, HHF 35 ( red) with nuclei are counterstained green. Thick arrows indicate single cells stained with antibodies to both PDGF and SMC and the thin arrow demonstrates a cell stained with the antibody to PDGF only. $(E)$ neointima double stained with PGF-007 (brown) and the macrophage marker, HAM 56 (blue) with nuclei counterstained red. $\times 400(A$, $B) ; \times 1,000(C, D, E)$. 
Table I. Concentration* of PDGF Isoforms in Tissue Extracts by ELISA

\begin{tabular}{lccc}
\hline & Graft matrix & Neointima & Platelets \\
\hline PDGF-AA $^{\ddagger 8}$ & $15.7 \pm 6.2$ & $2.8 \pm 1.0$ & $<0.3$ \\
PDGF-AB $^{1 / 5}$ & $13.8 \pm 5.2$ & $<0.2$ & $<0.4$ \\
PDGF-BB $^{15}$ & $4.0 \pm 0.9$ & $0.04 \pm 0.05$ & $36.3 \pm 6.7$ \\
\hline
\end{tabular}

* ng PDGF/ml tissue extract (not normalized to weight of starting material). Data expressed as mean \pm SEM of values obtained with three to five dilutions of each sample. $¥$ Capture with monoclonal anti-A antibody (127.2.2.2), secondary rabbit polyclonal anti-A.

"Capture with monoclonal anti-B antibody (PGF 007), secondary rabbit polyclonal anti-A. " Capture with monoclonal anti-B antibody (PGF 007), secondary rabbit polyclonal anti-B. ${ }^{\S}$ Although limited cross-reactivity exists with these antibody combinations for alternate dimeric forms of PDGF, evaluation of standard curves for these alternate forms suggests that in none of these samples could the levels detected be explained to any significant extent by the alternate forms (data not shown).

in Fig. 8. No comparable bands were observed when the blots were probed with an antibody against the PDGFR- $\alpha$ subunit, although the antibody did recognize $\alpha$-subunits in control cells (data not shown).

\section{Discussion}

All three dimeric forms of PDGF are present in tissue extracts from this primate model of vessel wall assembly and retain mitogenic potency for vascular SMC in culture. In the neointima, PDGF-A mRNA and protein are selectively expressed near the lumen and in larger amounts than PDGF-B. In the interstices of the graft, both PDGF-A and -B are present in readily detectable quantities as hetero- and homodimers while baboon platelets contain almost exclusively PDGF-BB. These results establish that cells within the healing graft possess the ability to synthesize PDGF. We propose that PDGF may help mediate cell infiltration (neovascularization) of the graft material as well as subsequent neointimal development.

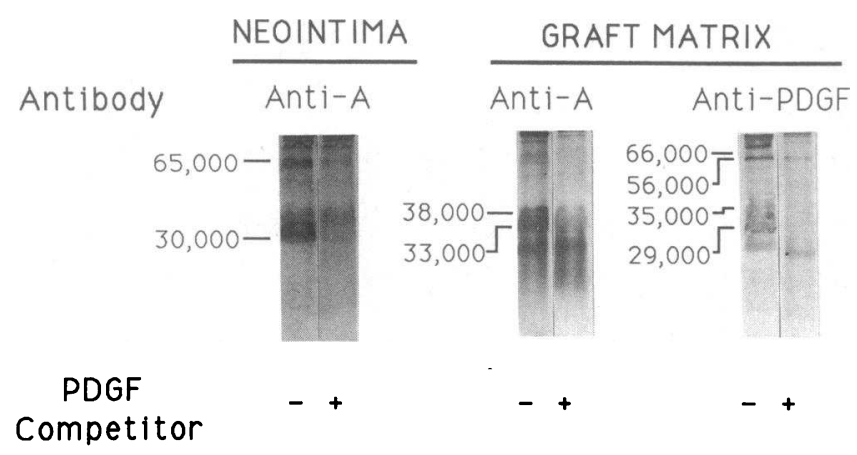

Figure 5. Western blot analysis of graft extracts for PDGF protein. Extracts of the graft neointima and matrix were analyzed after separation in a $15 \%$ nonreducing SDS polyacrylamide gel and transfer to nitrocellulose. The Western blot was analyzed with a rabbit polyclonal anti-PDGF-A antibody (Anti-A) or a goat affinity-purified polyclonal antibody that recognizes all three dimeric forms of PDGF (Anti$P D G F)$. The PDGF competitor for the blots probed with Anti-A was PDGF-AA; for the blots probed with anti-PDGF, PDGF-AB was the competitor.

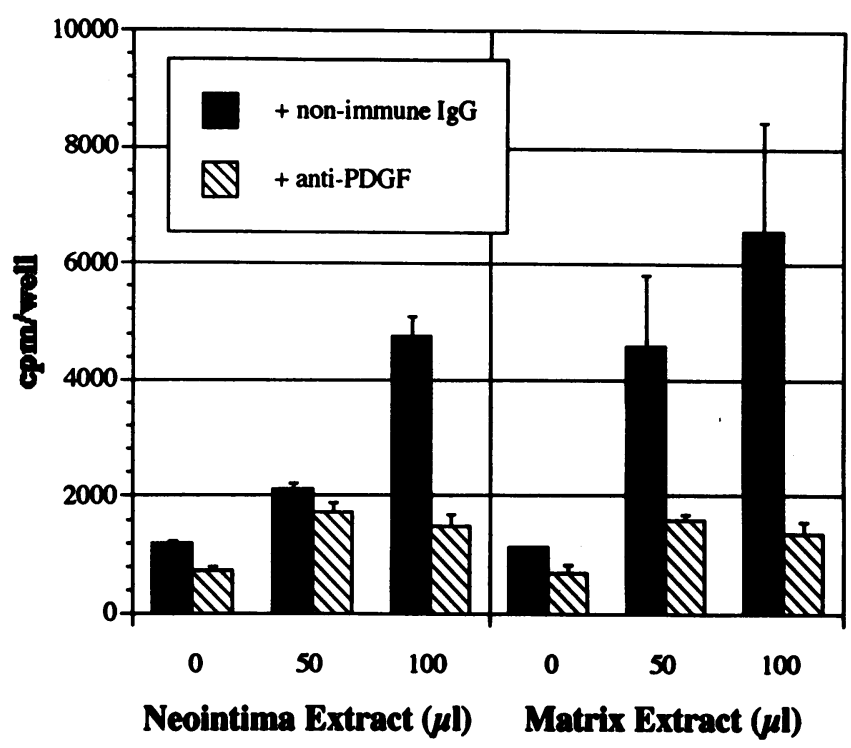

Figure 6. PDGF-like mitogenic activity in extracts of PTFE grafts. 50 $\mu \mathrm{l}$ or $100 \mu \mathrm{l}$ of the indicated extracts were tested in the presence of nonimmune IgG or anti-PDGF IgG and a dose response was observed with both matrix and neointimal extracts. The difference in counts between wells incubated with nonimmune IgG and anti-PDGF represents the amount of mitogenic activity that can be attributed to PDGF-like material. Values represent mean $( \pm S D)$ of triplicate determinations. Note that addition of anti-PDGF reduces thymidine incorporation to near basal levels.

PDGF from macrophages may promote cellular infiltration of the graft matrix. The PTFE grafts elicit a foreign body inflammatory response in the host animal. The macrophage, activated by contact with a prosthetic material resistant to phagocytosis, is the pivotal cell in the foreign body response. Histologic and immunochemical analysis of the PTFE graft matrix demonstrates an overwhelming predominance of macrophages and
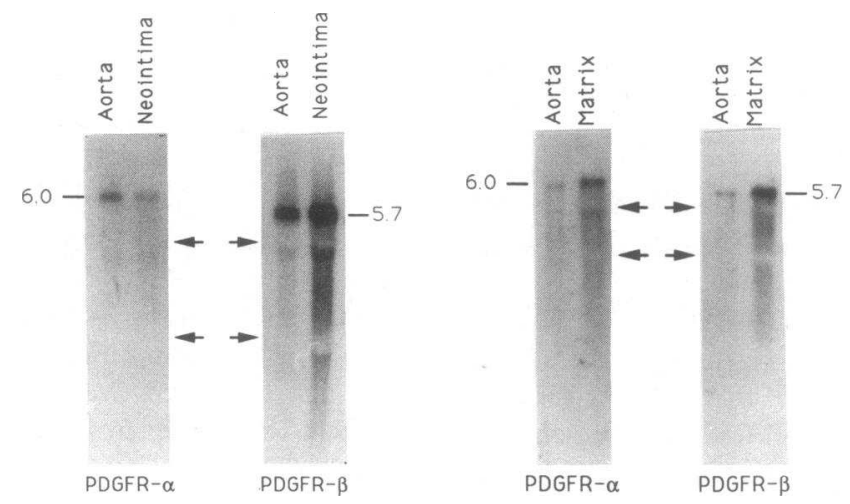

A

B

Figure 7. Analysis of PDGF receptor mRNA expression in PTFE grafts. Northern blots of graft neointima $(A)$ and graft matrix $(B)$ were compared with normal aorta for PDGF receptor subunit $\alpha$ and $\beta$ expression levels. Arrows represent position of $18 \mathrm{~S}$ and $28 \mathrm{~S}$ rRNA. Note the decreased expression of PDGFR- $\alpha$ and increased expression of PDGFR- $\beta$ in graft neointima relative to normal aorta while both receptor subunits are expressed to a greater degree in graft matrix than normal aorta. 

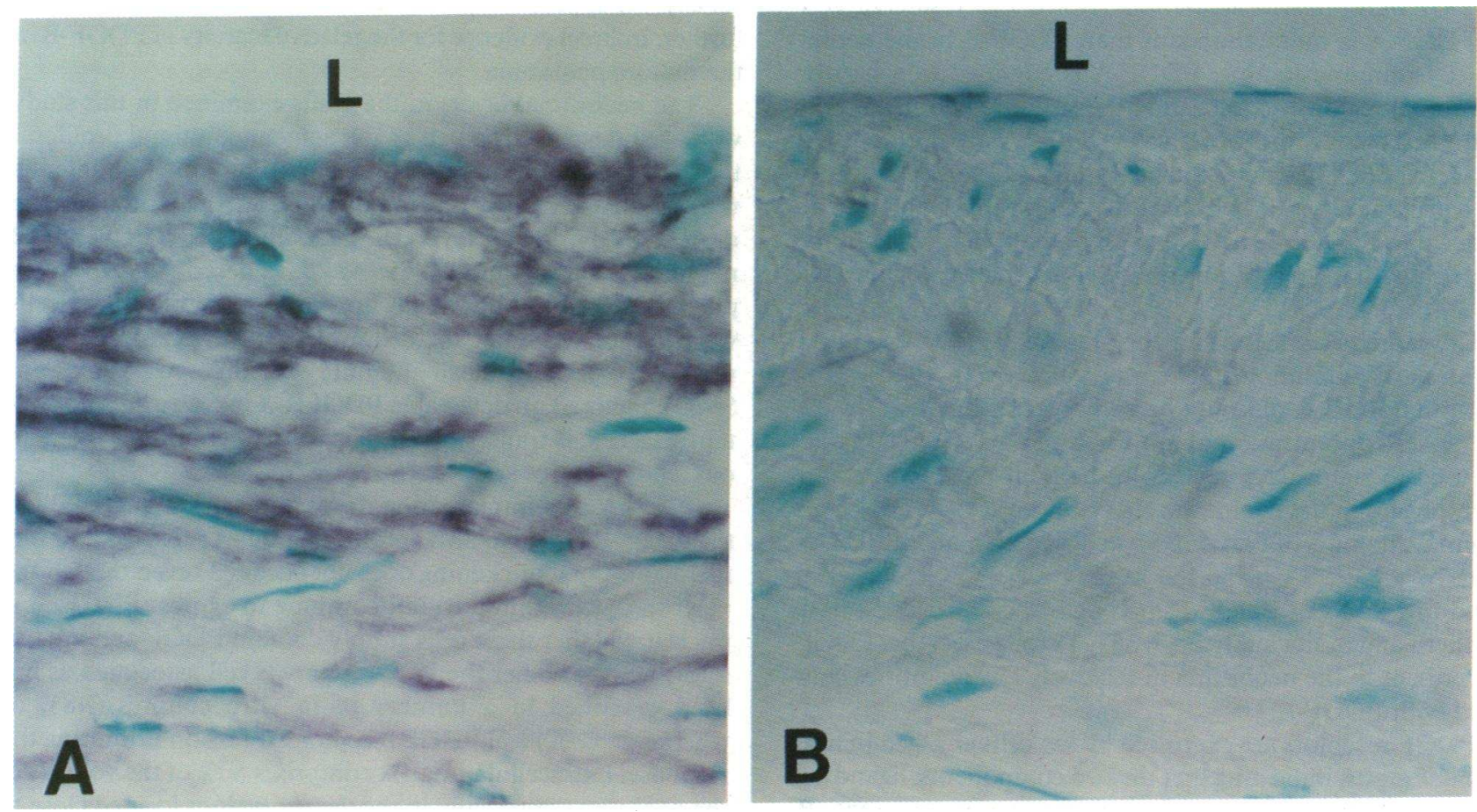

Figure 8. Immunohistochemical analysis of PDGF receptor $\beta$-subunit protein expression in graft neointima $(A)$ compared to normal aorta $(B)$ using the monoclonal antibody PR7212. The graft neointima contains much more PDGFR- $\beta$ protein than normal aorta. $\times 1,000$.

multinucleate giant cells, both of which stain prominently for PDGF-A and -B. This is distinct from other forms of vascular injury such as hypercholesterolemia-induced atherosclerosis in which macrophages stain for PDGF-B chain but not the Achain (Sasahara, M., E. W. Raines, and R. Ross, unpublished observations).

Both Northern and in situ hybridization studies of the graft matrix indicate that both PDGF receptor genes are also expressed at measurable levels. Western blots of matrix extract demonstrate only PDGFR- $\beta$ protein. Hence, the macrophage, the predominant cell type in the graft matrix, expresses PDGF and may express receptors as well. While Claesson-Welch et al. (37) found no evidence of PDGFR- $\beta$ expression by freshly

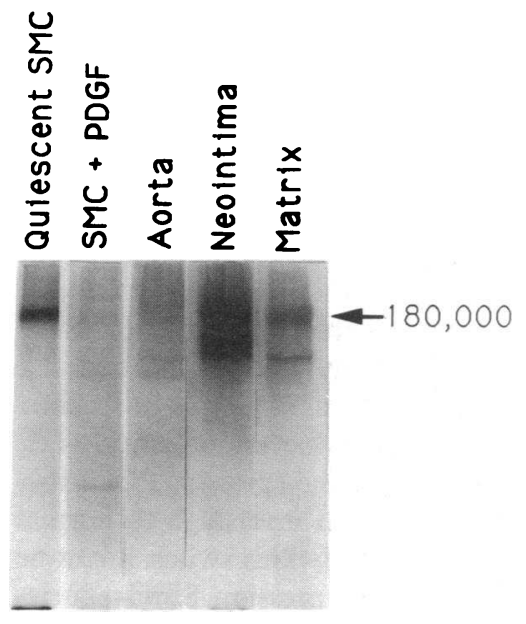

Figure 9. Western blot analysis of PTFE graft extracts for the presence of PDGF receptor $\beta$-subunit protein using the monoclonal antibody PR7212. Note the relatively abundant $\mathrm{ex}-$ pression of PDGFR- $\beta$ protein in graft neointima and matrix compared to normal aorta. Quiescent baboon aortic SMC served as a positive control while SMC incubated with PDGF (to downregulate PDGFR expression) was used as a negative control. isolated human blood monocytes, Pantazis et al. (38) reported expression and production of PDGFR- $\beta$ in phorbol estertreated monocytic leukemia cell lines. Perhaps foreign body activation of macrophages induces expression of PDGFR- $\beta$ in a similar manner as phorbol ester. However, it is also possible that macrophages may increase the expression of PDGF receptors in mesenchymal cells within the matrix. This phenomenon has been reported to occur in inflamed joints and atherosclerotic vessels (39-41). Because we were unable to perform immunostaining with PR7212 on the graft matrix, the specific cells responsible for PDGFR- $\beta$ expression have not been identified.

The luminal surface of the PTFE grafts in this model reendothelializes by transmural migration of microvessels derived from the surrounding granulation tissue (2). Whether PDGF directly participates in angiogenesis is not known. In general, endothelial cells do not respond to PDGF although microvascular endothelial cells in the central nervous system can express PDGFR- $\beta(42,43)$ and synthesize DNA in response to PDGF$B B(43)$. Thus, it is possible that macrophage-derived PDGF could participate in the angiogenic response that occurs in the early phases of PTFE graft healing. However, other known angiogenic factors may also be present in the graft matrix macrophages.

Along with endothelial cells, SMC must also traverse the graft to contribute to neointimal formation. Recent studies from our laboratories using a rat carotid artery injury model suggest that while PDGF possesses some mitogenic potency for SMC in vivo, its major role is to promote SMC migration from the media into the intima $(44,45)$. Macrophage-derived PDGF in the graft matrix might similarly induce infiltration of perigraft SMC into the prosthetic material, initiating the migratory response ultimately necessary for neointimal thickening. 
PDGF may promote neointimal growth. Our results suggest that PDGF-A is more abundant than PDGF-B in the neointima. By immunostaining, PDGF-A is confined to a narrow periluminal region encompassing the surface endothelial cells and the first few layers of SMC and PDGF-AA was the predominant form of PDGF detected in neointimal extracts. These findings agree with in situ hybridization studies by Golden et al. that localized PDGF-A mRNA to this region (7), which is the same region that contains the majority of proliferating neointimal SMC.

The principal evidence for the presence of PDGF-B in the neointima is immunohistochemical (Fig. $3 \mathrm{~B}$ ). PDGF-B in neointimal SMC could only be demonstrated by using a $32-$ fold higher concentration of anti-B antibody (PGF-007) than was used to stain macrophages in the graft matrix. Scattered macrophages in the neointima also contained PDGF B-chain. Minimal amounts of PDGF-B were detected in neointimal extracts by an ELISA using the same antibody. Golden et al. found low levels of PDGF-B mRNA in neointimal tissue by Northern and in situ analysis $(7,36)$. Thus, we feel that PDGF$B$ is present in the neointima in relatively low quantities compared with PDGF-A.

PDGF receptors are expressed by the cells engaged in healing these grafts, indicating that the two components, ligand and receptor, necessary for a biological response are present. By Northern, in situ hybridization, and immunochemical analyses, PDGFR- $\beta$ is widely distributed in the neointima, and is expressed by SMC in the same areas that stain with anti-PDGF antibodies. By ELISA and mRNA analysis, however, PDGF-A, which requires the PDGFR- $\alpha$, appears to be the most abundantly expressed ligand in the neointima.

In a different model of injury and repair, balloon injury of the rat carotid artery, Majesky et al. (46) also noted upregulation of PDGF-A gene expression against the background of constitutive, unchanging PDGFR- $\alpha$ expression during the first week after injury. At later times, the developed intima expressed increased PDGF-A along with PDGFR- $\beta$ and minimal PDGF-B or PDGFR- $\alpha$. There are, however, important differences between the baboon graft healing model and the rat carotid injury model. In the injured rat carotid, the luminal cells are SMC while in the graft model they are endothelial cells. In the injured artery, SMC stop growing in the endothelialized regions, while in the grafts, SMC proliferate beneath the endothelium. Despite these differences, the pattern of PDGF ligand and receptor expression in the two models is similar, suggesting a fundamental response by vascular tissue to perturbed conditions.

Since PDGF-AA can only bind to the PDGFR- $\alpha$, the present findings and those of Majesky et al. (46) seem incompatible with a PDGF-regulated growth control mechanism. However, several possible alternative explanations exist.

Some PDGFR- $\alpha$ mRNA is present in the graft neointima by Northern analysis (Fig. $7 A$ ) as is some PDGF-B ligand which could bind to the more abundant PDGFR- $\beta$. It is unclear how much PDGFR- $\alpha$ or PDGF-B is necessary to generate and sustain a mitogenic response in vivo or when such expression is necessary. In addition, the normal biological response of nontransformed mesenchymal cells exposed to PDGF is receptor downregulation through internalization and degradation ( reviewed in reference 8 ). Thus, it would not be surprising that PDGFR- $\alpha$ expression is suppressed by the presence of high levels of PDGF-A, as exists in the periluminal region. Con- versely, the apparent high levels of PDGFR- $\beta$ might be taken as further, indirect evidence for the relative scarcity of PDGF-B in the mature neointima.

The neointimal layers in the grafts examined in this study were well developed; much of the active neointimal proliferation and thickening had already occurred by 2 mo (3). If grafts were studied at earlier time points when SMC are proliferating more actively, higher levels of either PDGFR- $\alpha$ or PDGF-B might be found. Sjolund et al. (47) have described just such a phenomenon in cultured rat aortic SMC. When these cells were induced to enter the cell cycle, an increase in PDGFR mRNA (especially the $\alpha$-subunit) was observed. Quiescent SMC contained no detectable PDGFR- $\alpha$ message but did contain PDGFR- $\beta$ transcript, similar to the neointimal tissue in our study.

2-3 mo after implantation, these grafts have "matured" to the extent that active SMC proliferation has subsided and further neointimal thickening does not occur (3) even though the macrophages within the graft continue to express PDGF. It is unclear whether these cells simply contain PDGF and are not releasing it, whether the PDGF remains cell associated as has been described in a number of in vitro cultures (48), or whether lack of local PDGF receptor expression is limiting the response. Extracellular matrix comprises $80 \%$ of the volume of the neointima, especially in the deeper regions located close to the graft material (5). This could further limit diffusion of PDGF released by macrophages in the graft matrix. PDGF is known to stimulate the production of connective tissue proteins either directly or indirectly, e.g., through TGF- $\beta$ (49-55). Thus, PDGF elaborated by macrophages in the graft matrix at earlier stages may have been involved in stimulating the synthesis and deposition of extracellular matrix by SMC deep in the neointima through a number of pathways.

Regulation of PDGF or growth factor expression. In this model, SMC proliferate just underneath the endothelium. This observation has caused us to suggest that events at the luminal surface may control the expression of factors which govern the SMC proliferative response. In a previous study (3), the luminal endothelial cells in these PTFE grafts were shown to be proliferating at levels above background yet there was no increase in endothelial density. This finding led to the conclusion that some form of chronic, nondenuding endothelial injury was occurring at the luminal surface. This injury represents one possible mechanism by which growth factors may be released from endothelial cells as previously shown in cultured endothelial cells treated with phorbol ester (56). Alternatively, cycling cells might synthesize and secrete more mitogen than resting cells. However, these PTFE grafts typically cease to thicken 2-3 mo after implantation, despite the apparently constant presence of PDGF-A.

What stops the thickening process? In other studies in this prosthetic graft model, neointimal SMC proliferation was shown to be inhibited by increased blood flow velocity and shear stress $(4,5)$. As neointimal thickening progressively narrows the lumen, the shear stress experienced by the surface endothelial cells increases exponentially. It is possible that at a certain level of thickening, a critical shear stress level is reached that shuts off a mitogenic signal in the endothelium (i.e., PDGF-B) or induces an inhibitory signal (perhaps PDGFR- $\alpha$ downregulation). Conversely, a switch from high to normal flow stimulated SMC proliferation (4). This switch might be associated with an increase in PDGF expression. Similar corre- 
lations between shear stress and intimal thickening have been demonstrated in other models (57-59). The nature of the growth regulatory signal modulated by shear stress is currently undefined.

Conclusion. Our studies demonstrate increased expression of both chains of PDGF and both receptor subunits in healing baboon PTFE grafts 2 mo after implantation. The expression of PDGF and it receptors is localized and specific to particular regions of the graft. PDGF-A and PDGFR- $\beta$ predominate in the neointima while the graft matrix contains both ligands and the PDGFR- $\beta$ receptor. The presence of the PDGFR- $\alpha$ subunit has been more difficult to define but our results suggest the existence of $\alpha$-subunit mRNA in the matrix and, at lower levels, in the neointima. The factors responsible for induction of this pattern of expression are unclear but the increased expression and colocalization of PDGF and its receptor in the neointima and graft matrix suggest that PDGF may be involved in SMC accumulation as well as the foreign body response in these grafts.

\section{Acknowledgments}

The authors gratefully acknowledge the valuable technical assistance of Bonnie Ashleman, Marina Ferguson, Elaine Yamanaka, Scott Coats, and Andrew Augustine.

Supported by grants HL-30946 (to A. W. Clowes), HL-18645 (to R. R. Ross, E. W. Raines, A. W. Clowes), GM35501 (to D. BowenPope) and RR00166 (to the Regional Primate Research Center) from the National Institutes of Health, United States Public Health Service and by a grant from the American Heart Association, Washington Affiliate (to L. W. Kraiss). All procedures involving live animals were performed in the facilities of the Regional Primate Research Center at the University of Washington.

The PTFE grafts used in this study were a generous gift of the W. L. Gore and Associates, Flagstaff, AZ. We gratefully acknowledge Mochida Pharmaceutical, Tokyo, Japan, for providing the PDGF-B monoclonal antibody (PGF 007). We also thank Davis and Geck (Danbury, CT) for their gift of polypropylene suture (Surgilene).

\section{References}

1. Schwartz, S. M., R. L. Heimark, and M. W. Majesky. 1990. Developmental mechanisms underlying pathology of arteries. Physiol. Rev. 70:1177-1209.

2. Clowes, A. W., T. R. Kirkman, and M. A. Reidy. 1986. Mechanisms of arterial graft healing: rapid transmural capillary ingrowth provides a source of intimal endothelium and smooth muscle in porous PTFE prostheses. Am. J. Pathol. 123:220-230.

3. Reidy, M. A., S. S. Chao, T. R. Kirkman, and A. W. Clowes. 1986. Endothelial regeneration. VI. Chronic non-denuding injury in baboon vascular grafts. Am. J. Pathol. 123:432-439.

4. Kohler, T. R., T. R. Kirkman, L. W. Kraiss, B. K. Zierler, and A. W. Clowes. 1991. Increased blood flow inhibits neointimal hyperplasia in endothelialized vascular grafts. Circ. Res. 69:1557-1565.

5. Kraiss, L. W., T. R. Kirkman, T. R. Kohler, B. K. Zierler, and A. W. Clowes. 1991. Shear stress regulates smooth muscle proliferation and neointimal thickening in porous polytetrafluoroethylene grafts. Arteriosclerosis Thromb. 11:1844-1852.

6. Zacharias, R. K., T. R. Kirkman, R. D. Kenagy, D. F. Bowen-Pope, and A. W. Clowes. 1988. Growth factor production by polytetrafluoroethylene vascular grafts. J. Vasc. Surg. 7:606-610.

7. Golden, M. A., Y. P. T. Au, T. R. Kirkman, J. N. Wilcox, E. W. Raines, R. Ross, and A. W. Clowes. 1991. Platelet-derived growth factor activity and mRNA expression in healing vascular grafts in baboons. J. Clin. Invest. 87:406-414.

8. Raines, E. W., D. F. Bowen-Pope, and R. Ross. 1990. Platelet-derived growth factor. In Handbook of Experimental Pharmacology: Peptide Growth Factors and Their Receptors I. M. B. Sporn and A. B. Roberts, editors. SpringerVerlag New York Inc. 173-262.

9. Hart, C. E., M. Bailey, D. A. Curtis, S. Osborn, E. Raines, R. Ross, and
J. W. Forstrom. 1990. Purification of PDGF-AB and PDGF-BB from human platelet extracts and identification of all three PDGF dimers in human platelets. Biochemistry. 29:166-172.

10. Ross, R., J. A. Glomset, B. Kariya, and L. Harker. 1974. A platelet-dependent serum factor that stimulates the proliferation of arterial smooth muscle cells in vitro. Proc. Natl. Acad. Sci. USA. 71:1207-1210.

11. DiCorleto, P. E., and D. F. Bowen-Pope. 1983. Cultured endothelial cells produce a platelet-derived growth factor-like protein. Proc. Natl. Acad. Sci. USA. 80:1919-1923.

12. Seifert, R. A., S. M. Schwartz, and D. F. Bowen-Pope. 1984. Developmentally regulated production of platelet-derived growth factor-like molecules. $\mathrm{Na}$ ture (Lond.). 311:669-671.

13. Barret, T. B., and E. P. Benditt. 1988. Platelet-derived growth factor gene expression in human atherosclerotic plaques and normal artery wall. Proc. Natl. Acad. Sci. USA. 85:2810-2814.

14. Hart, C. E., J. W. Forstrom, J. D. Kelly, R. A. Seifert, R. A. Smith, R. Ross, M. J. Murray, and D. F. Bowen-Pope. 1988. Two classes of PDGF receptor recognize different isoforms of PDGF. Science (Wash. DC). 240:1529-1531.

15. Heldin, C.-H., G. Backstrom, A. Ostman, A. Hammacher, L. Ronnstrand, K. Rubin, M. Nister, and B. Westermark. 1988. Binding of different dimeric forms of PDGF to human fibroblasts: evidence for two separate receptor types. EMBO (Eur. Mol. Biol. Organ.) J. 7:1387-1393.

16. Seifert, R. A., C. E. Hart, P. E. Phillips, J. W. Forstrom, R. Ross, M. J. Murray, and D. F. Bowen-Pope. 1989. Two different subunits associate to create isoform-specific platelet-derived growth factor receptors. J. Biol. Chem. 264:8771-8778.

17. Kelly, J. D., B. A. Haldeman, F. J. Grant, M. J. Murray, R. A. Seifert, D. F. Bowen-Pope, J. A. Cooper, and A. Kazlauskas. 1991. PDGF stimulates PDGF receptor dimerization and intersubunit transphosphorylation. J. Biol. Chem. 266:8987-8992.

18. Cathala, G., J. F. Savouret, and B. Mendez. 1983. A method for isolation of intact translationally active ribonucleic acid. DNA (NY). 2:329-335.

19. Betsholtz, C., A. Johnsson, C.-H. Heldin, B. Westermark, P. Lind, M. S. Urdea, R. Eddy, T. B. Shows, K. Philpott, A. L. Mellor, T. J. Knott, and J. Scott. 1986. cDNA sequence and chromosomal localization of human platelet-derived growth factor A-chain and its expression in tumour cell lines. Nature (Lond.). 320:695-699.

20. Ratner, L., S. F. Josephs, R. Jarrett, M. S. Reitz, Jr., and F. Wong-Staal. 1985. Nucleotide sequence of transforming human c-sis cDNA clones with homology to platelet-derived growth factor. Nucleic Acids Res. 13:5007-5013.

21. Gronwald, R. G., F. J. Grant, B. A. Haldeman, C. E. Hart, P. J. O'Hara, F. S. Hagen, R. Ross, D. F. Bowen-Pope, and M. J. Murray. 1988. Cloning and expression of a cDNA coding for the human platelet-derived growth factor receptor: evidence for more than one receptor class. Proc. Natl. Acad. Sci. USA 85:3435-3439.

22. Wilcox, J. N., K. M. Smith, L. T. Williams, S. M. Schwartz, and D. Gordon. 1988. Platelet-derived growth factor mRNA detection in human atherosclerotic plaques by in situ hybridization. J. Clin. Invest. 82:1134-1143.

23. Wilcox, J. N., K. M. Smith, S. M. Schwartz, and D. Gordon. 1989. Localization of tissue factor in the normal vessel wall and in the atherosclerotic plaque. Proc. Natl. Acad. Sci. USA. 86:2839-2843.

24. Josephs, S. F., L. Ratner, M. F. Clarke, E. H. Westin, M. S. Reitz, and F. Wong-Staal. 1984. Transforming potential of human c-sis nucleotide encoding platelet-derived growth factor. Science (Wash. DC). 225:636-639.

25. Lee, K. H., D. F. Bowen-Pope, and R. R. Reed. 1990. Isolation and characterization of the alpha platelet-derived growth factor receptor from rat olfactory epithelium. Mol. Cell. Biol. 10:2237-2246.

26. Escobedo, J. A., S. Navankasatussas, L. S. Cousens, S. R. Coughlin, G. I. Bell, and L. T. Williams. 1988. A common PDGF receptor is activated by homodimeric A and B forms of PDGF. Science (Wash. DC). 240:1532-1534.

27. Melton, D. A., P. A. Krieg, M. R. Rebagliati, T. Maniatis, K. Zinn, and M. R. Green. 1984. Efficient in vitro synthesis of biologically active RNA and RNA hybridization probes from plasmids containing a bacteriophage SP6 promoter. Nucleic Acids Res. 12:7035-7056.

28. Shiraishi, T., S. Morimoto, K. Itoh, H. Sato, K. Sugihara, T. Onishi, and T. Ogihara. 1989. Radioimmunoassay of human platelet-derived growth factor using monoclonal antibody toward a synthetic 73-97 fragment of its B-chain. Clin. Chim. Acta. 184:65-74.

29. Ross, R., J. Masuda, E. W. Raines, A. M. Gown, S. Katsuda, M. Sasahara, L. T. Malden, H. Masuko, and H. Sato. 1990. Localization of PDGF-B protein in macrophages in all phases of atherogenesis. Science (Wash. DC). 248:10091012.

30. Hart, C. E., R. A. Seifert, R. Ross, and D. F. Bowen-Pope. 1987. Synthesis, phosphorylation, and degradation of multiple forms of the platelet-derived growth factor receptor studied using a monoclonal antibody. J. Biol. Chem. 262:10780-10785.

31. Tsukada, T., D. Tippens, D. Gordon, R. Ross, and A. M. Gown. 1987. HHF35, a muscle-actin-specific monoclonal antibody. Am. J. Pathol. 126:51-60.

32. Gown, A. M., T. Tsukada, and R. Ross. 1986. Human atherosclerosis. II. 
Immunocytochemical analysis of the cellular composition of human atherosclerotic lesions. Am. J. Pathol. 125:191-207.

33. Sasahara, M., J. W. U. Fries, E. W. Raines, A. M. Gown, L. E. Westrum, M. P. Frosch, D. T. Bonthron, R. Ross, and T. Collins. 1991. PDGF B-chain in neurons of the central nervous system, posterior pituitary, and in a transgenic model. Cell. 64:217-227.

34. Raines, E. W., S. K. Dower, and R. Ross. 1989. Interleukin-1 mitogenic activity for fibroblasts and smooth muscle cells is due to PDGF-AA. Science (Wash. DC). 243:393-396.

35. Raines, E. W., and R. Ross. 1985. Purification of human platelet-derived growth factor. Methods Enzymol. 109:749-772.

36. Golden, M. A., Y. P. T. Au, R. D. Kenagy, and A. W. Clowes. 1990. Growth factor gene expression by intimal cells in healing polytetrafluoroethylene grafts. J. Vasc. Surg. 11:580-585.

37. Claesson-Welsh, L., A. Eriksson, A. Moren, L. Severinsson, B. Ek, A. Ostman, C. Betsholtz, and C.-H. Heldin. 1988. cDNA cloning and expression of a human platelet-derived growth factor (PDGF) receptor specific for a B-chaincontaining PDGF molecule. Mol. Cell. Biol. 8:3476-3486.

38. Pantazis, P., S. Kharbanda, A. S. Goustin, T. Galanapoulos, and D. Kufe 1991. Coexpression of the genes for platelet-derived growth factor B-chain receptor and macrophage colony-stimulating factor 1 receptor during monocyte differentiation. Proc. Natl. Acad. Sci. USA. 88:2481-2485.

39. Rubin, K., L. Terracio, L. Ronnstrand, C.-H. Heldin, and L. Klareskog. 1988. Expression of platelet-derived growth factor receptors is induced on connective tissue cells during chronic synovial inflammation. Scand. J. Immunol. 27:285-294.

40. Rubin, K., A. Tingstrom, G. K. Hansson, E. Larsson, L. Ronnstrand, L. Klareskog, L. Claesson-Welch, C.-H. Heldin, B. Fellstrom, and L. Terracio. 1988. Induction of B-type receptors for platelet-derived growth factor in vascular inflammation: possible implications for development of vascular proliferative lesions. Lancet. i:1353-1356.

41. Reuterdahl, C., A. Tingstroem, L. Terracio, K. Funa, C. H. Heldin, and K Rubin. 1991. Characterization of platelet-derived growth factor beta-receptor expressing cells in the vasculature of human rheumatoid synovium. Lab. Invest. 64:321-329.

42. Hermansson, M., M. Nister, C. Betsholtz, C.-H. Heldin, B. Westermark, and $\mathrm{K}$. Funa. 1988. Endothelial cell hyperplasia in human glioblastoma: coexpression of mRNA for platelet-derived growth factor (PDGF) B chain and PDGF receptor suggests autocrine growth stimulation. Proc. Natl. Acad. Sci. USA. 85:7748-7752.

43. Smits, A., M. Hermansson, M. Nister, I. Karnushina, C.-H. Heldin, B. Westermark, and K. Funa. 1989. Rat brain capillary endothelial cells express functional PDGF B-type receptors. Growth Factors. 2:1-8.

44. Jawien, A., D. F. Bowen-Pope, V. Lindner, S. M. Schwartz, and A. W. Clowes. 1992. Platelet-derived growth factor promotes smooth muscle migration and intimal thickening in a rat model of balloon angioplasty. J. Clin. Invest. 89:507-511.

45. Ferns, G. A., E. W. Raines, K. H. Sprugel, A. S. Motani, M. A. Reidy, and
R. Ross. 1991. Inhibition of neointimal smooth muscle accumulation after angioplasty by an antibody to PDGF. Science (Wash. DC). 253:1129-1132.

46. Majesky, M. W., M. A. Reidy, D. F. Bowen-Pope, C. E. Hart, J. N. Wilcox, and S. M. Schwartz. 1990. PDGF ligand and receptor gene expression during repair of arterial injury. J. Cell Biol. 111:2149-2158.

47. Sjolund, M., M. Rahm, L. Claesson-Welsh, T. Sejersen, C.-H. Heldin, and J. Thyberg. 1990. Expression of PDGF $\alpha$ - and $\beta$-receptors in rat arterial smooth muscle cells is phenotype and growth state dependent. Growth Factors. 3:191203.

48. Raines, E. W., and R. Ross. 1992. Compartmentalization of PDGF on extracellular binding sites dependent on exon-6-encoded sequences. J. Cell Biol. 116:533-543.

49. Pierce, G. F., J. Vande Berg, R. Rudolph, J. Tarpley, and T. A. Mustoe. 1991. Platelet-derived growth factor-BB and transforming growth factor beta 1 selectively modulate glycosaminoglycans, collagen, and myofibroblasts in excisional wounds. Am. J. Pathol. 138:629-646.

50. Cromack, D. T., B. Porras-Reyes, and T. A. Mustoe. 1990. Current concepts in wound healing: growth factor and macrophage interaction. J. Trauma. 30(Suppl. 12):S129-133.

51. Pierce, G. F., T. A. Mustoe, J. Lingelbach, V. R. Masakowski, G. L. Griffin, R. M. Senior, and T. F. Deuel. 1989. Platelet-derived growth factor and transforming growth factor-beta enhance tissue repair activities by unique mechanisms. J. Cell Biol. 109:429-440.

52. Grotendorst, G. R., G. R. Martin, D. Pencev, J. Sodek, and A. K. Harvey. 1985. Stimulation of granulation tissue formation by platelet-derived growth factor in normal and diabetic rats. J. Clin. Invest. 76:2323-2329.

53. Sprugel, K. H., J. M. McPherson, A. W. Clowes, and R. Ross. 1987. Effects of growth factors in vivo. I. Cell ingrowth into porous subcutaneous chambers. Am. J. Pathol. 129:601-613.

54. Lawrence, W. T., M. B. Sporn, C. Gorschboth, J. A. Norton, and G. R. Grotendorst. 1986. The reversal of an adriamycin-induced healing impairment with chemoattractants and growth factors. Ann. Surg. 203:142-147.

55. Lynch, S. E., J. C. Nixon, R. B. Colvin, and H. N. Antoniades. 1987. Role of platelet-derived growth factor in wound healing: synergistic effects with other growth factors. Proc. Natl. Acad. Sci. USA. 84:7696-7700.

56. Fox, P. L., and P. E. DiCorleto. 1984. Regulation of production of a platelet-derived growth factor-like protein by cultured bovine aortic endothelial cells. J. Cell. Physiol. 121:298-308.

57. Ku, D. N., D. P. Giddens, C. K. Zarins, and S. Glagov. 1985. Pulsatile flow and atherosclerosis in the human carotid bifurcation: positive correlation between plaque location and low and oscillating shear stress. Arteriosclerosis. 5:293-302.

58. Rittgers, S. E., P. E. Panayotis, J. F. Guy, R. M. Nerem, G. M. Shaw, J. R. Hostetler, and J. S. Vasko. 1978. Velocity distribution and intimal proliferation in autologous vein grafts in dogs. Circ. Res. 42:792-801.

59. Dobrin, P. B., F. N. Littooy, and E. D. Endean. 1989. Mechanical factors predisposing to intimal hyperplasia and medial thickening in autogenous vein grafts. Surgery (St. Louis). 105:393-400. 